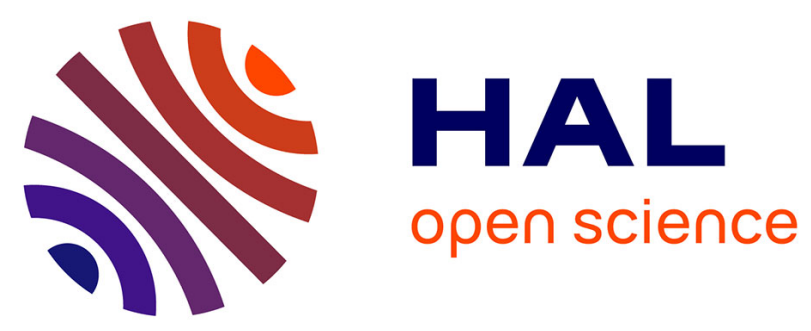

\title{
Processing and characterization of aluminium-based MMCs produced by gas pressure infiltration
}

\author{
E. Carreno Morelli, Thierry Cutard, R. Schaller, C. Bonjour
}

\section{To cite this version:}

E. Carreno Morelli, Thierry Cutard, R. Schaller, C. Bonjour. Processing and characterization of aluminium-based MMCs produced by gas pressure infiltration. MATERIALS SCIENCE AND ENGINEERING. A, STRUCTURAL MATERIALS, 1998, 251 ( $\left.\mathrm{n}^{\circ} 1-2\right)$, p. 48-57. 10.1016/S09215093(98)00649-2 . hal-01847833

\section{HAL Id: hal-01847833 https://hal.science/hal-01847833}

Submitted on 6 Nov 2019

HAL is a multi-disciplinary open access archive for the deposit and dissemination of scientific research documents, whether they are published or not. The documents may come from teaching and research institutions in France or abroad, or from public or private research centers.
L'archive ouverte pluridisciplinaire HAL, est destinée au dépôt et à la diffusion de documents scientifiques de niveau recherche, publiés ou non, émanant des établissements d'enseignement et de recherche français ou étrangers, des laboratoires publics ou privés. 


\title{
Processing and characterization of aluminium-based MMCs produced by gas pressure infiltration
}

\author{
E. Carreño-Morelli a,*, T. Cutard ${ }^{1, a}$, R. Schaller ${ }^{a}$, C. Bonjour ${ }^{b}$ \\ a Ecole Polytechnique Féderale de Lausanne, Institut de Génie Atomique, PHB-Écublens, CH-1015 Lausanne, Switzerland \\ ${ }^{\mathrm{b}}$ Ecole d'Ingénieurs du Valais, route de Rawyl 47, CH-1950 Sion, Switzerland
}

\begin{abstract}
A device has been designed and built for unidirectional infiltration of ceramic preforms with a molten metal. It allows production of $\mathrm{Al}$ or $\mathrm{Mg}$ alloys reinforced with short or continuous ceramic fibres. The apparatus has been tested for different alloys and preforms by varying the process parameters (infiltration pressure, fibre content, melt superheat, preform preheat and solidification speed). As an example, full infiltration of $\mathrm{Al}_{2} \mathrm{O}_{3}-$ SAFFIL chopped preforms with an $\mathrm{Al}-4 \mathrm{wt} . \% \mathrm{Cu}-1 \mathrm{wt} . \% \mathrm{Mg}-$ $0.5 \mathrm{wt} . \% \mathrm{Ag}$ alloy has been achieved under controlled conditions by using a gas pressure between 1 and $3 \mathrm{MPa}$. The resulting metal matrix composite has been characterised by microscopical observations and mechanical tests. Measurements of Young's modulus, density, microhardness and mechanical loss show that the optimal process conditions for $\mathrm{Al}-4 \mathrm{wt} . \% \mathrm{Cu}-1 \mathrm{wt} . \% \mathrm{Mg}-0.5 \mathrm{wt} . \% \mathrm{Ag}-$ SAFFIL composites are a temperature of $750^{\circ} \mathrm{C}$ for both preform and melt and the maximum infiltration pressure of $3 \mathrm{MPa}$. Preliminary tests have shown that the gas pressure infiltration apparatus is also suitable to produce continuous fibre reinforced and hybrid metal matrix composites.
\end{abstract}

Keywords: Aluminium; Gas pressure infiltration; Magnesium; Metal-matrix composites

\section{Introduction}

Liquid metal infiltration of ceramic preforms is a usual route to produce metal matrix composites (MMCs) [1,2]. In particular, squeeze casting provides good infiltration quality of chopped preforms $[3,4]$. This procedure consists of pushing the molten metal into a preheated preform using a piston and pressures in the range 50-100 MPa. Despite the good results obtained with this technique, some difficulties remain related with air entrapment into the preform $[5,6]$ which can be at the origin of voids at metalceramic interphases, with detrimental consequences to the mechanical properties. An additional problem is related to the high pressure involved in the process, which implies the development of heavy equipment even for laboratory research. Moreover, high pres-

\footnotetext{
* Corresponding author. Tel.: + 4121 6933708; fax: + 4121 6934470; e-mail: morelli@igahpse.epfl.ch

${ }^{1}$ Present address: Ecole des Mines d'Albi-Carmaux, Centre Matériaux, F81013 Albi, France.
}

sure could produce fibre damage or an inhomogeneous fibre distribution along the infiltration direction [3].

In order to overcome these problems, special attention has been devoted to low pressure infiltration processes [7-10]. With respect to squeeze casting, the infiltration pressure can be substantially reduced if the vacuum is made in the preform to avoid air entrapment [11]. Consequently, relatively low-cost facilities can be developed using a gas pressure to achieve infiltration. In this work, a prototype of a gas pressure infiltration device which has been developed for MMCs processing at the laboratory scale is presented. This prototype is based on the idea that alloy melting and preform infiltration should be done separately. Consequently, the apparatus is divided into two parts: a melting chamber, where the alloy is melted under vacuum or protective atmosphere, and an injection chamber, where the molten metal is pushed into the preform by gas pressure. The two chambers are isolated from each other by a high pressure valve. 


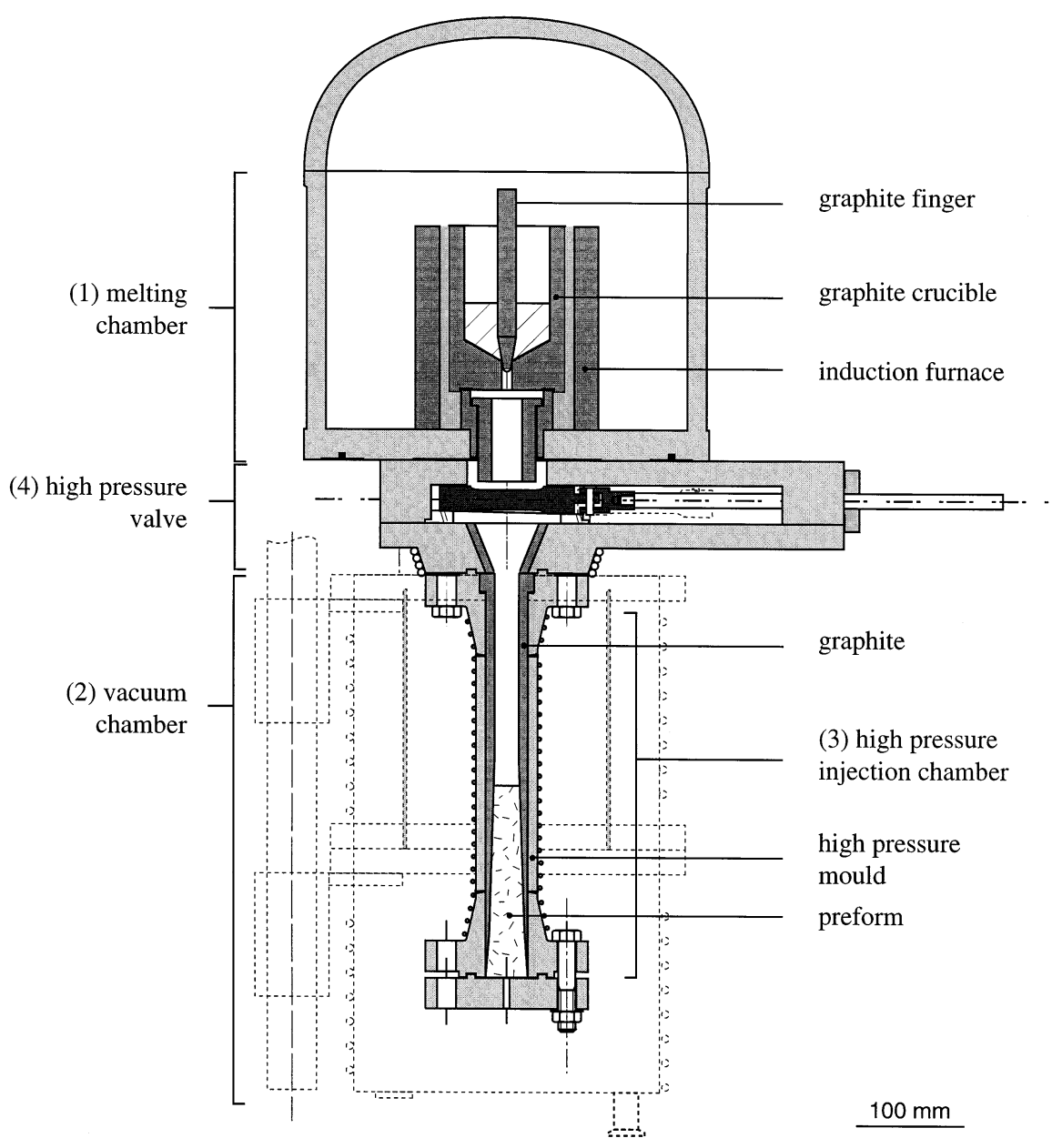

Fig. 1. Schematic drawing of the gas pressure infiltration device showing the melting and the vacuum chambers. The high pressure valve allows one to isolate the melting chamber from the injection chamber (which is inside the vacuum chamber).

\section{Experimental}

\subsection{Gas pressure infiltration device: description and operation}

Fig. 1 shows a schematic drawing of the gas pressure infiltration apparatus where four major parts can be distinguished:

1. the melting chamber

2. the vacuum chamber

3. the injection chamber inside the vacuum chamber

4. the high pressure valve which allows one to isolate the melting and the injection chambers.

Vacuum can be achieved independently in each chamber as shown in Fig. 2 (using vacuum outlets Vv1, Vv2 and Vv3). The melting chamber is equipped with a Leybold ISG 0,5 (Leybold $\mathrm{GmbH}$, Köln, Germany) commercial induction furnace. The alloy is melted in a graphite crucible, the bottom of which is closed by an actuator-controlled graphite finger. The melt heating is monitored by a thermocouple located inside the graphite finger.
The vacuum chamber provides isolation of the injection chamber during preform preheating, casting and solidification. Actually, both the vacuum and injection chambers are connected by a $1 \mathrm{~mm}$ diameter conduct which allows one to continue with the preform outgasing even during casting. In addition, this avoids any possibility of gas entrapment into the preform.

The injection chamber is composed of a cylindrical high pressure vessel made of a high temperature refractory alloy (Haynes $230 \mathrm{Ni}-\mathrm{Cr}-\mathrm{W}$ alloy, from NickelContor, Zürich, Switzerland) and of an inner graphite (type R8650 from Steinemann AG, Chur, Switzerland) mould in which the preform is located. The preform is rod-shaped with a slightly conical geometry in order to facilitate its extraction through the bottom entry port of the mould. The preform can be pre-heated up to $800^{\circ} \mathrm{C}$ by a THERMOCOAX ${ }^{\circledR}$ (Philips AG, Dietikon, Switzerland) heater wound around the injection chamber. Five thermocouples installed at different heights in the external wall of the injection chamber (Fig. 2) allow one to sense the evolution of the temperature, which is 


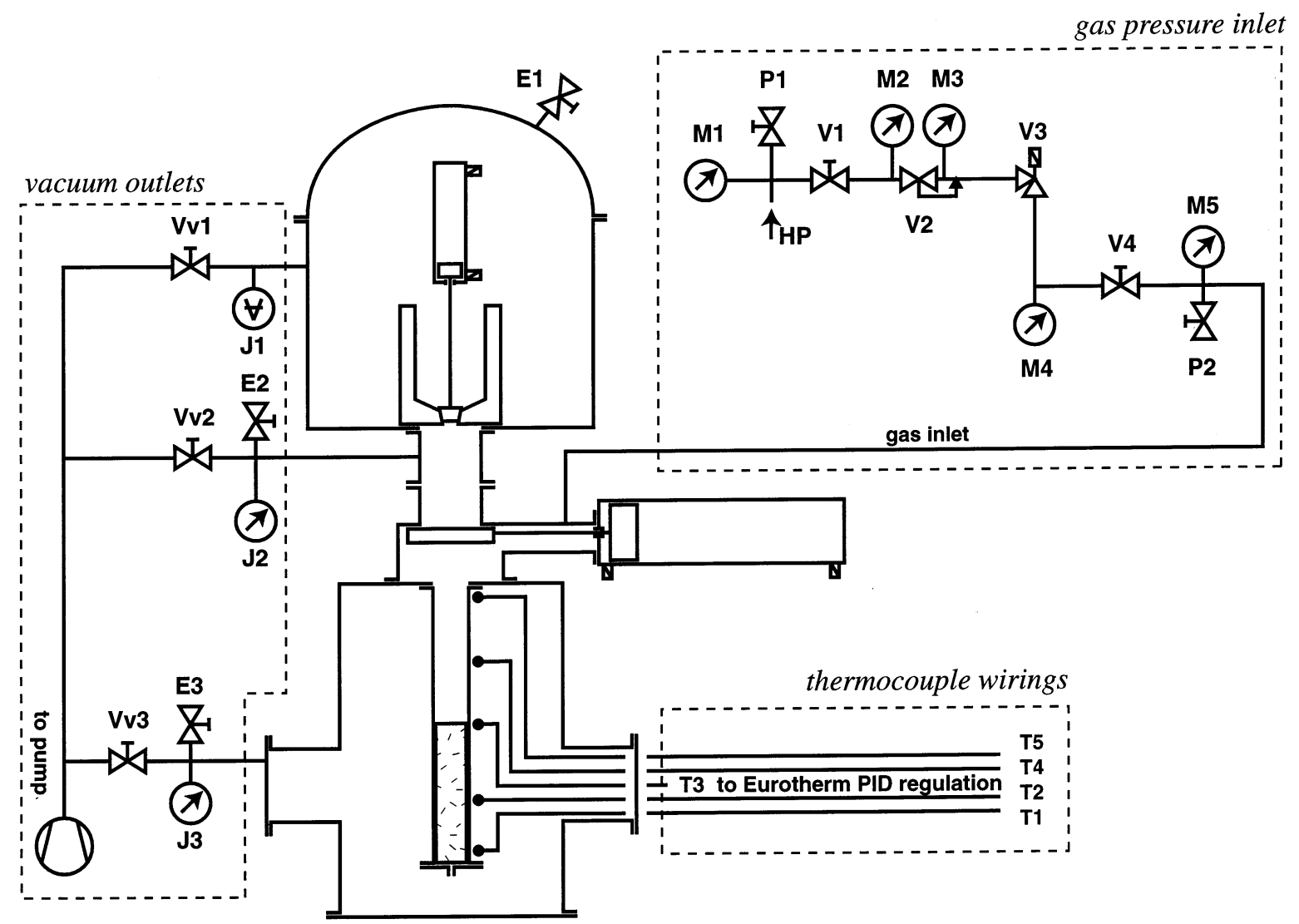

Fig. 2. Schematic drawing showing the vacuum outlets (Vv1, Vv2, Vv3), the vacuum gauges (J1, J2, J3), the gas inlet with the hand driven valve $\mathrm{V} 4$, and thermocouple wirings.

(a)

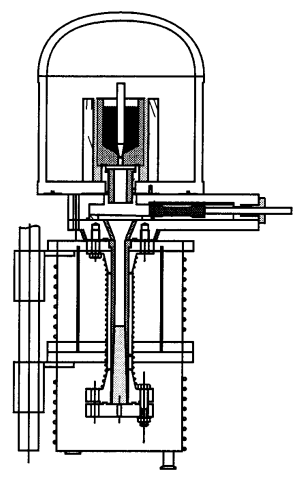

(b)

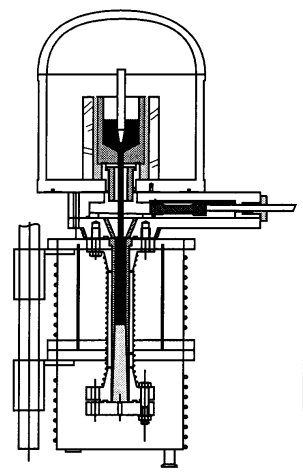

(c)

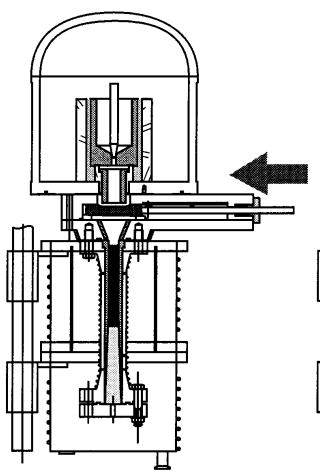

(d)

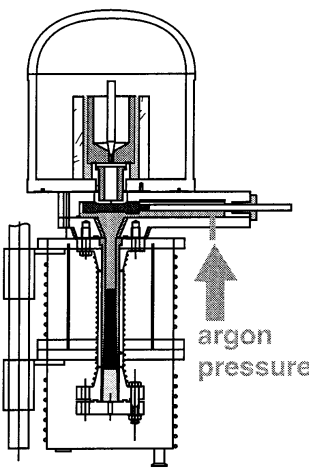

(e)

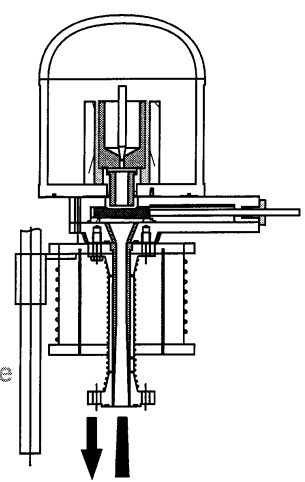

Fig. 3. Operation in the gas pressure infiltration device: (a) melting, (b) casting, (c) gate valve closing, (d) injection, (e) de-moulding.

Table 1

Summary of infiltration parameters

\begin{tabular}{lllll}
\hline Specimen & Fibre content [\% vol.] & Infiltration pressure $[\mathrm{MPa}]$ & Melt superheat $\left[{ }^{\circ} \mathrm{C}\right]$ & Preform preheat $\left[{ }^{\circ} \mathrm{C}\right]$ \\
\hline A & 15 & 1 & 780 & 755 \\
B & 15 & 2 & 780 & 755 \\
C & 15 & 3 & 780 & 755 \\
D & 15 & 2 & 780 & 750 \\
E & 25 & 3 & 780 & 750 \\
F & 25 & 3 & 750 & 750 \\
G & 25 & 3 & 750 & 700 \\
\hline
\end{tabular}


Table 2

Density, Young's modulus and mechanical loss maximum height for $\mathrm{Al}-4 \mathrm{wt} . \% \mathrm{Cu}-1 \mathrm{wt} . \% \mathrm{Mg}-0.5 \mathrm{wt} . \% \mathrm{Ag}$ reinforced with $25 \mathrm{vol} . \% \mathrm{SAFFIL}$ processed with different fabrication parameters

\begin{tabular}{lllllll}
\hline Specimen & Infiltration pressure $[\mathrm{MPa}]$ & Melt superheat $\left[{ }^{\circ} \mathrm{C}\right]$ & Preform preheat $\left[{ }^{\circ} \mathrm{C}\right]$ & $\rho\left[\mathrm{g} \mathrm{cm}^{3}\right]$ & $E[\mathrm{GPa}]$ & $\operatorname{tg} \phi_{\max }\left[10^{-3}\right]$ \\
\hline $\mathrm{D}$ & 2 & 780 & 750 & 2.81 & 86.8 & 3.9 \\
$\mathrm{E}$ & 3 & 780 & 750 & 2.88 & 86.5 & 7.3 \\
$\mathrm{~F}$ & 3 & 750 & 750 & 2.92 & 96.0 & 11.2 \\
$\mathrm{G}$ & 3 & 750 & 700 & 2.90 & 88.5 & 6.7 \\
\hline
\end{tabular}

computer-monitored during the operation. The central thermocouple T3 is connected to a Eurotherm 902P (Eurotherm, Durrington, West Sussex, England) controller which ensures the temperature regulation during preform preheating. After infiltration the preform is cooled down by a forced cold air stream which flows in a helical circuit around the injection chamber. Different

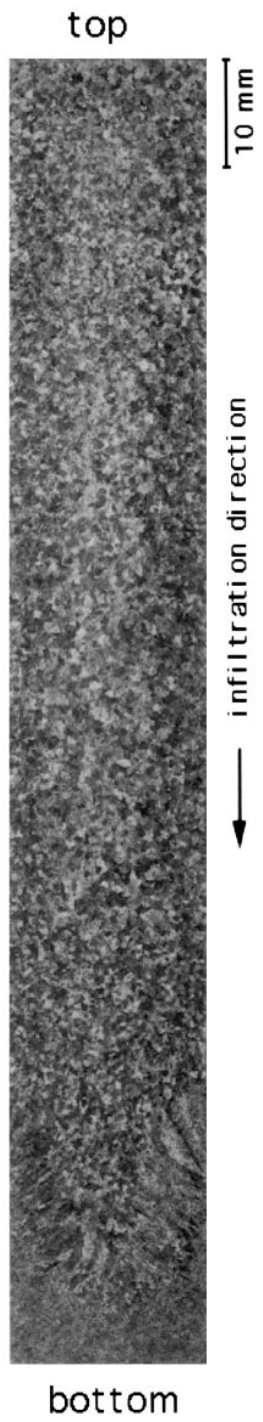

Fig. 4. Macrograph of the as-processed MMC rod after gas pressure infiltration.

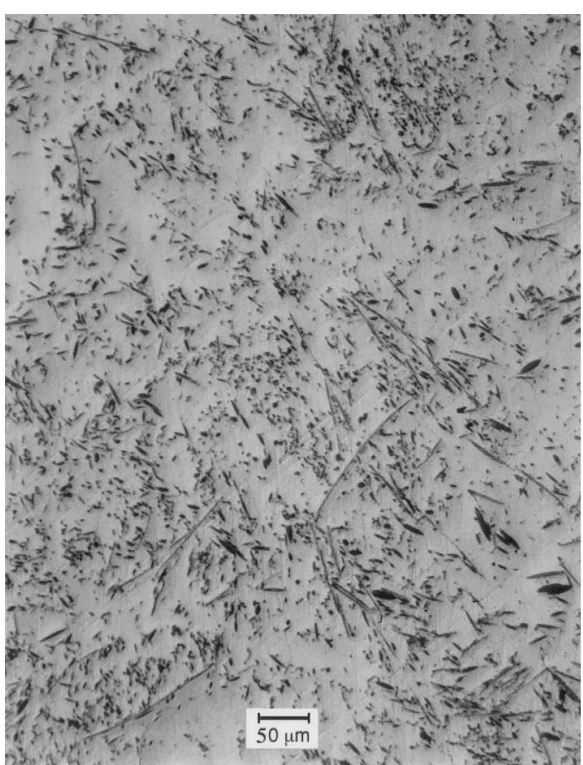

(a)

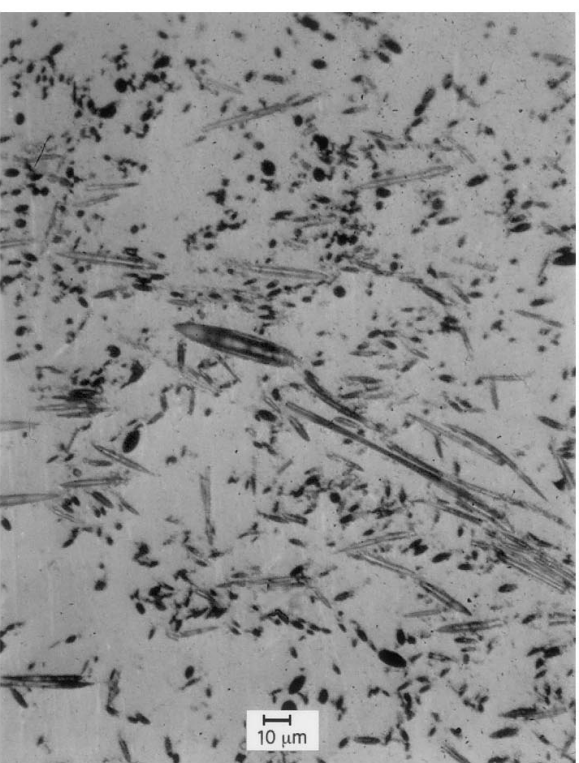

(b)

Fig. 5. Optical micrographs of $\mathrm{Al}-4 \mathrm{wt} . \% \mathrm{Cu}-1 \mathrm{wt} . \% \mathrm{Mg}-0.5 \mathrm{wt} . \% \mathrm{Ag}$ reinforced with $15 \mathrm{vol} . \%$ SAFFIL processed with an infiltration pressure of $2 \mathrm{MPa}$. 
solidification speeds can be obtained by varying the air flux or the air temperature. The cooling time to room temperature is about $15 \times 10^{3} \mathrm{~s}$ for free cooling, and can be reduced to $5 \times 10^{3} \mathrm{~s}$ by using the cold air stream.

The high-pressure valve which separates the injection chamber from the melting chamber is a vacuum gate valve specially reinforced to work under pressures as high as $5 \mathrm{MPa}$. Closing and opening movements are made by an electro-pneumatic actuator. A graphite guide is placed between the crucible and the mould in order to protect the valve and to guide the metal into the mould. The high pressure valve allows one to restrict the high pressure zone to the small volume of the mould.

The principle of operation is shown schematically in Fig. 3. As a first step, vacuum $(\approx 1 \mathrm{~Pa})$ is pulled in both the melting and injection chambers. The infiltrant metal is melted in the graphite crucible of the upper chamber by high frequency heating (a). Simultaneously, in the injection chamber the preform is preheated and

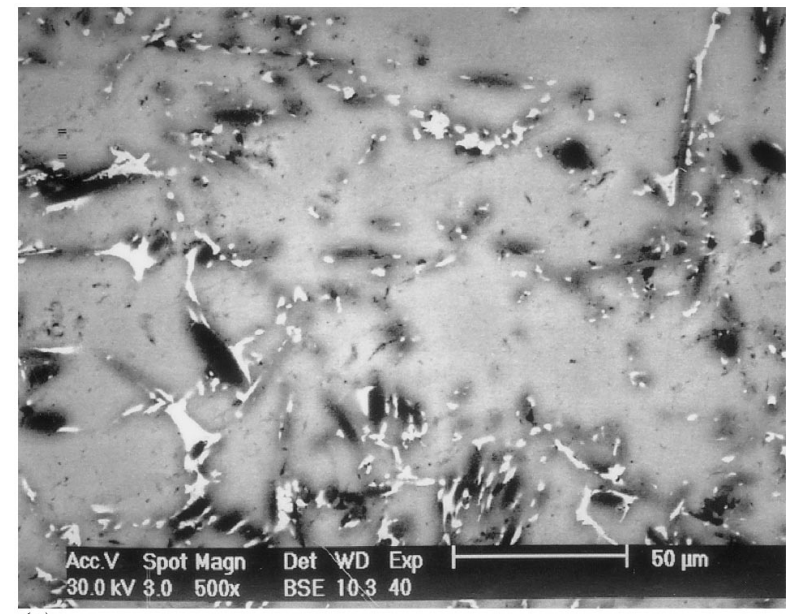

(a)

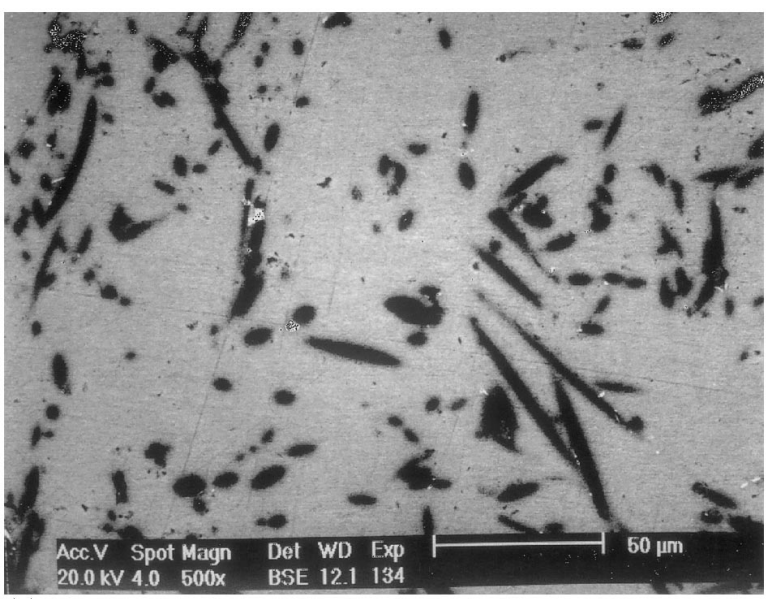

(b)

Fig. 6. SEM micrographs of $\mathrm{Al}-4 \mathrm{wt} . \% \mathrm{Cu}-1 \mathrm{wt} . \% \mathrm{Mg}-0.5 \mathrm{wt} . \% \mathrm{Ag}$ reinforced with $15 \mathrm{vol} . \% \mathrm{SAFFIL}$ (a) as-cast and (b) after solution treatment of $2 \mathrm{~h}$ at $480^{\circ} \mathrm{C}+2 \mathrm{~h}$ at $500^{\circ} \mathrm{C}$.
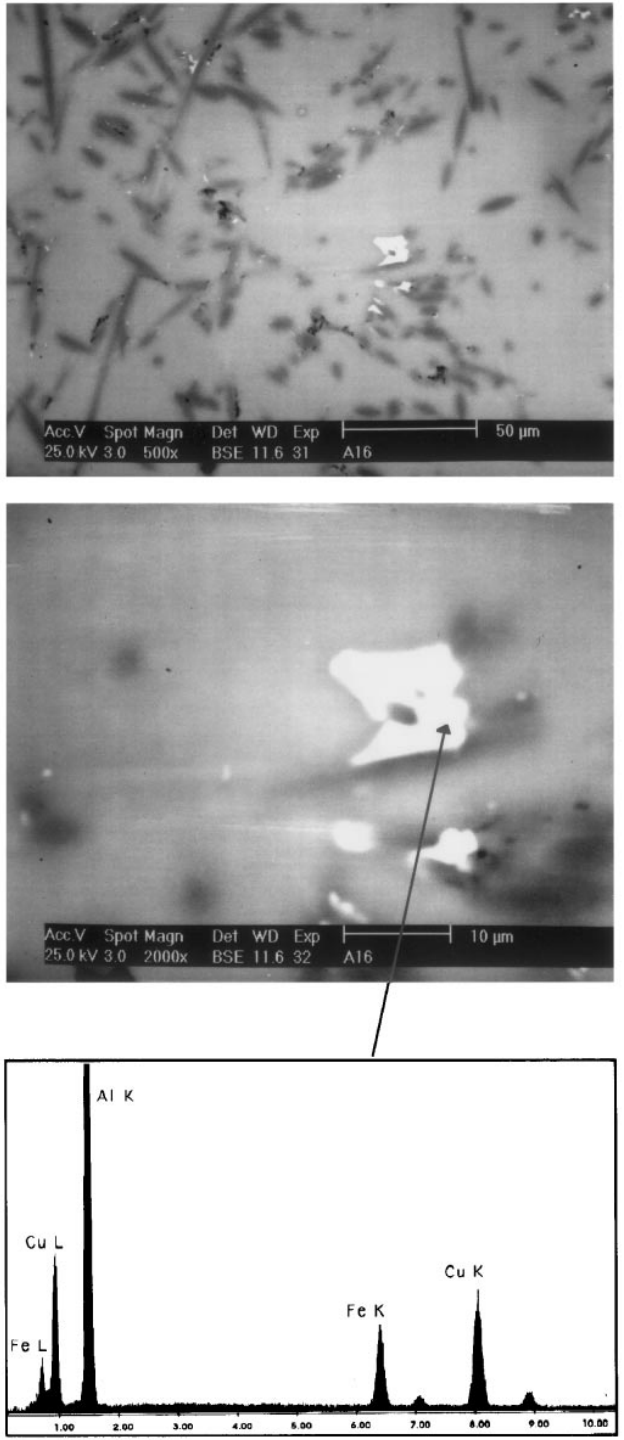

Fig. 7. Segregation of an $\mathrm{Al}-\mathrm{Cu}-\mathrm{Fe}$ phase around an $\mathrm{Al}_{2} \mathrm{O}_{3}$ fibre (EDS microanalysis).

outgassed. When the desired temperature of the molten metal as well as of the fibre preform are reached, the power for the preform preheating is switched off and the graphite finger is opened, allowing flow of the molten metal from the upper to the lower chamber (b). Then, the gate valve is closed (c) and argon is rapidly introduced until the desired pressure is reached in order to push the metal into the preform (d). Immediately thereafter, the casting is cooled by activation of the forced air stream. After solidification, the gas pressure is released by opening the pressure release valve P2 (see Fig. 2). When room temperature is reached, the resulting MMC rod is extracted by opening the bottom ports of both the vacuum and injection chambers (e).

Special attention is paid to minimizing the contact time between the molten metal and the ceramic reinforcement, in order to reduce the interphase reactions 
which could lead to composite strength degradation [7]. The time between the opening of the graphite finger and the activation of the forced air stream is about $10 \mathrm{~s}$. From the monitored temperatures $T 1$ and $T 2$ measured in the external wall of the injection chamber, an upper limit of $120 \mathrm{~s}$ can be estimated for the contact time. This is about one half of the corresponding value for free cooling.

2.2. Processing route. An example: $A l-4 w t . \% C u-$ $1 w t . \% \mathrm{Mg}-0.5 w t . \% \mathrm{Ag}$ reinforced with $\mathrm{Al}_{2} \mathrm{O}_{3}$ short Saffil fibres

\subsubsection{Preforms}

The reinforcing SAFFIL $\delta-\mathrm{Al}_{2} \mathrm{O}_{3}$ fibres were produced by ICI (UK) with nominal dimensions of 3-6 $\mu \mathrm{m}$ diameter and 40-100 $\mu \mathrm{m}$ length. Pseudo randomly oriented preforms of 15 and $25 \%$ fibre volume fraction were provided by Vernaware, UK. Preforms result from a slurry of SAFFIL fibres and silica binder which are compressed in a mould. As a result of the fabrication process, the fibre axis tend to be aligned normal to the pressing direction, which results in a two-dimensional random arrangement. Rodshaped preforms for gas pressure infiltration $(20 \mathrm{~mm}$ diameter, $120 \mathrm{~mm}$ length) were machined from the as-received preforms (size of $153 \mathrm{~mm} \times 153 \mathrm{~mm} \times 25$ $\mathrm{mm})$.

\subsubsection{Infiltration parameters}

Systematic production of $\mathrm{Al}-4 \mathrm{wt} . \% \mathrm{Cu}-1 \mathrm{wt} . \% \mathrm{Mg}-$ $0.5 \mathrm{wt} . \% \mathrm{Ag}$ reinforced with SAFFIL short fibres has been made by varying the infiltration parameters in order to optimize the production process (see Table $1)$. The process variables were the fibre content [15$25 \%$ vol.], the preform preheat $\left[700-750^{\circ} \mathrm{C}\right]$, the melt superheat $\left[700-800^{\circ} \mathrm{C}\right]$ and the infiltration pressure [1-3 MPa]. In order to reduce the contact time between molten metal and fibres, the maximum cooling speed after injection was used in all experiments. This was accomplished by setting the air flux to the maximum and by cooling the air in a liquid nitrogen bath before its entrance to the vacuum chamber. After processing, different thermal treatments were made for the as-cast specimens in order to identify conditions for an optimal mechanical behaviour.

\subsubsection{Characterization}

Optical and scanning electron microscopy were used to evaluate the infiltration quality, segregation, porosity and grain distribution. Specimens for metallographic observation were prepared by grinding through 600 grit papers followed by polishing with $6 \mu \mathrm{m}$ and $3 \mu \mathrm{m}$ diamond paste. The grain structure was revealed by chemical etching in a solution of 3 $\mathrm{ml} \mathrm{HCl}, 5 \mathrm{ml} \mathrm{HNO}_{3}, 2 \mathrm{ml} \mathrm{HF}, 190 \mathrm{ml} \mathrm{H} \mathrm{H}_{2} \mathrm{O}$ followed by lightly swabbing with a solution of $20 \% \mathrm{NO}_{3}$ fuming $/ 80 \% \quad \mathrm{H}_{2} \mathrm{O}$ to remove oxidation. The chemical composition of segregated products at interfaces was determined by EDS microanalysis in a Philips XL 30 FEG scanning electron microscope.

Mechanical properties were evaluated by measurement of Young's modulus $(E)$, density $(\rho)$, microhardness $(H V)$ and mechanical loss spectra [12]. Young's modulus was measured in a resonant bar apparatus which allows one to tune the resonant frequency $f(\approx \mathrm{kHz})$ in flexural mode for specimens of $4 \times 1 \times 50 \mathrm{~mm}$. $E$ is given by:

$E=0.971 \frac{l^{4}}{a^{2}} \rho f^{2}$

where $l$ and $a$ are the length and thickness of the specimen. Density measurements were made by comparing the weight of the samples immersed in air and water, and using the Archimedean principle. Microhardness testing was carried out with a Leitz Durimet apparatus using a Vickers indenter and a load of 500 g. For each microhardness measurement, five indentations were made and the average was used for calculating the Vickers hardness number $(H V)$. Mechanical loss spectra as a function of the temperature $\operatorname{tg} \phi$ versus $T$ ) were measured in an inverted torsion pendulum with forced oscillations during controlled heating and cooling cycles between 100 and $450 \mathrm{~K}$. Typical oscillation frequencies $f=0.1 \mathrm{~Hz}$, strain amplitudes $\varepsilon=10^{-5}$ and temperature change rates $\mathrm{d} T /$ $\mathrm{d} t=2 \mathrm{~K} \min ^{-1}$ were used.

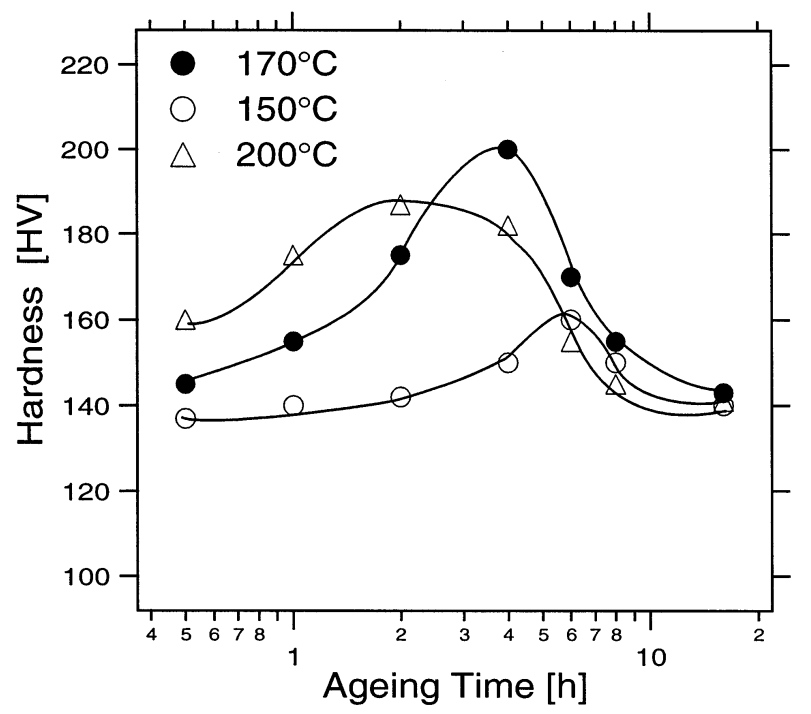

Fig. 8. Microhardness tests for $\mathrm{Al}-4 \mathrm{wt} . \% \mathrm{Cu}-1 \mathrm{wt} . \% \mathrm{Mg}-0.5 \mathrm{wt} . \% \mathrm{Ag}$ reinforced with $25 \mathrm{vol} \% \mathrm{SAFFIL}$, after solution treatment of $2 \mathrm{~h}$ at $480^{\circ} \mathrm{C}+2 \mathrm{~h}$ at $500^{\circ} \mathrm{C}$, water quenching and natural ageing of 4 days at room temperature. 

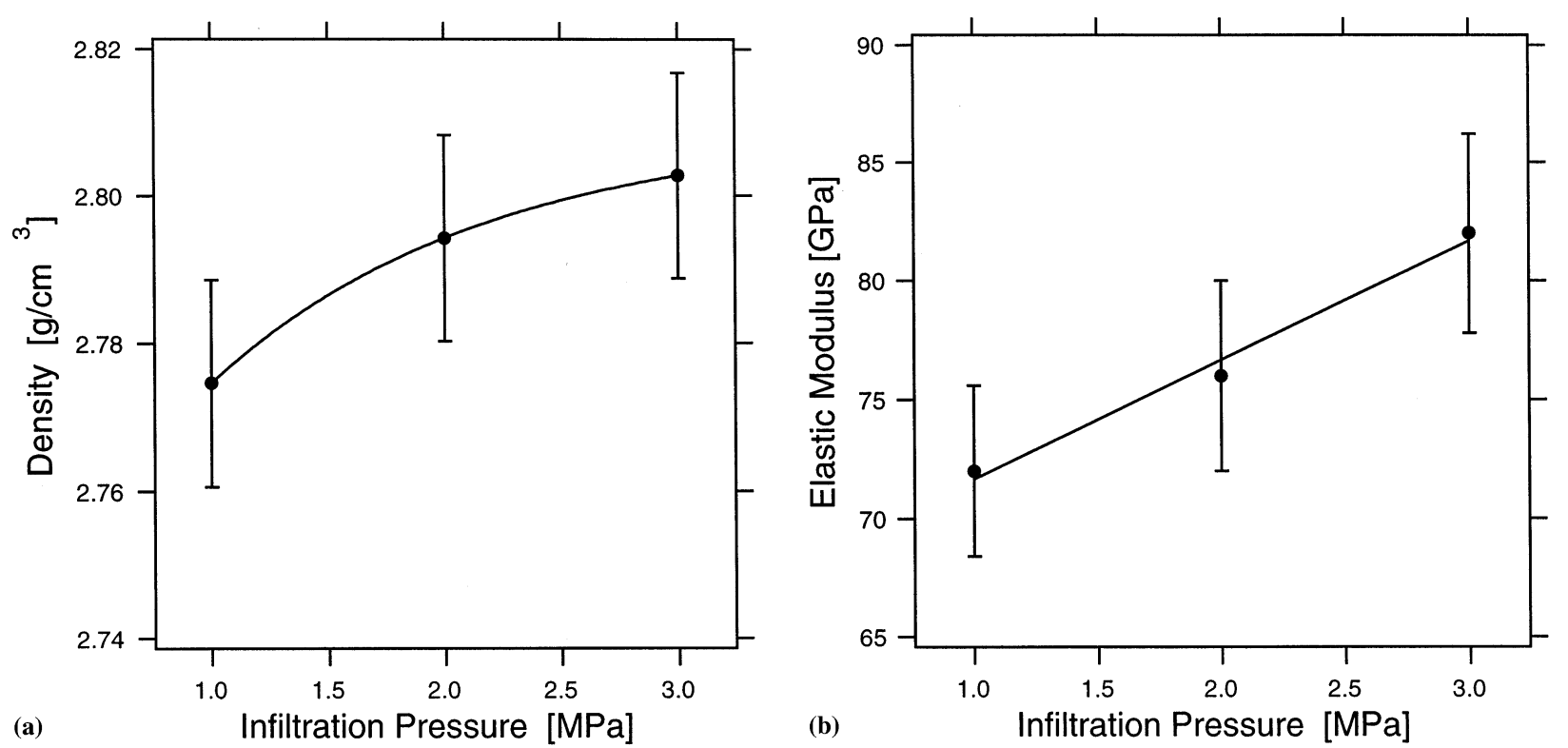

(a)

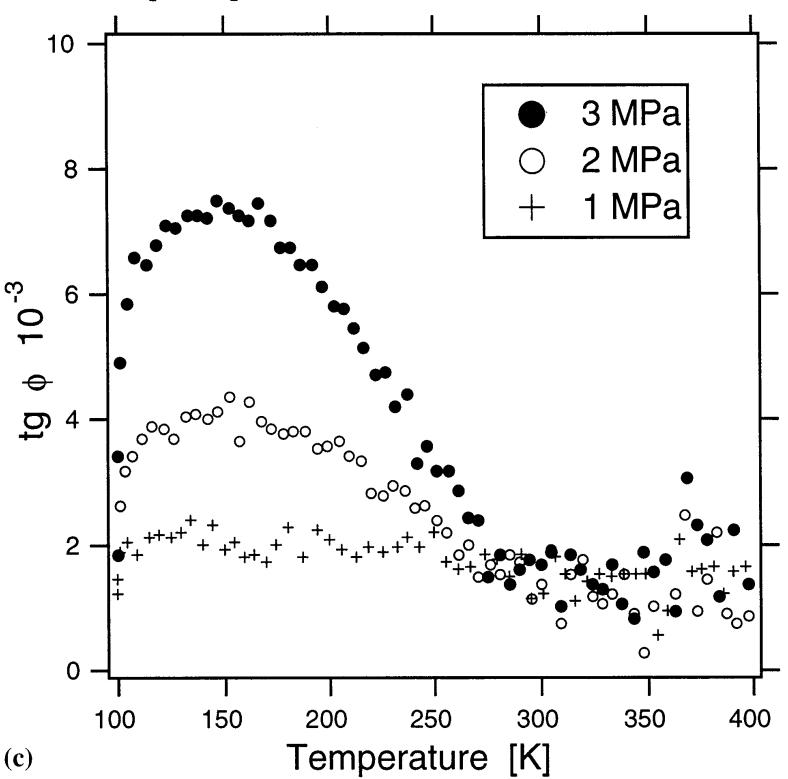

Fig. 9. Normalised density, Young's modulus and mechanical loss spectra for $\mathrm{Al}-4 \mathrm{wt} . \% \mathrm{Cu}-1 \mathrm{wt} . \% \mathrm{Mg}-0.5 \mathrm{wt} . \% \mathrm{Ag}$ reinforced with $15 \mathrm{vol} \%$ SAFFIL, processed with different infiltration pressures (specimens A, B and C, Table 1).

\section{Results}

Optical examination (Fig. 4) revealed a quite uniform grain structure along the MMC castings (rods of 20 $\mathrm{mm}$ diameter by $120 \mathrm{~mm}$ length). Only a $20 \mathrm{~mm}$ region at the bottom shows a columnar grain structure coming from the outset of solidification. Effectively, the air cooling circuit has been mounted so as to induce directional solidification from the bottom to the top of the preform. Grain size along castings seems to be controlled by the isotropic fibre arrangement [3].

No evidence of the presence of cavities at interfaces nor in the matrix was found with optical microscopy, which shows that full infiltration of the ceramic preform was obtained using the present gas pressure infiltration process (Fig. 5).

Scanning electron microscopy shows in the as-cast structure the existence of a segregated phase around the fibres (Fig. 6a) which have been identified as $\mathrm{Al}_{2} \mathrm{Cu}$ from EDS microanalysis. This phase, which is not desirable for mechanical properties, is almost completely dissolved after a two-stage solution treatment of $2 \mathrm{~h}$ at $480^{\circ} \mathrm{C}+2 \mathrm{~h}$ at $500^{\circ} \mathrm{C}$ (Fig. 6b). However, residual segregation persists due to the presence of iron as shown in Fig. 7. Iron is certainly present in the aluminium alloy before infiltration, since during the 


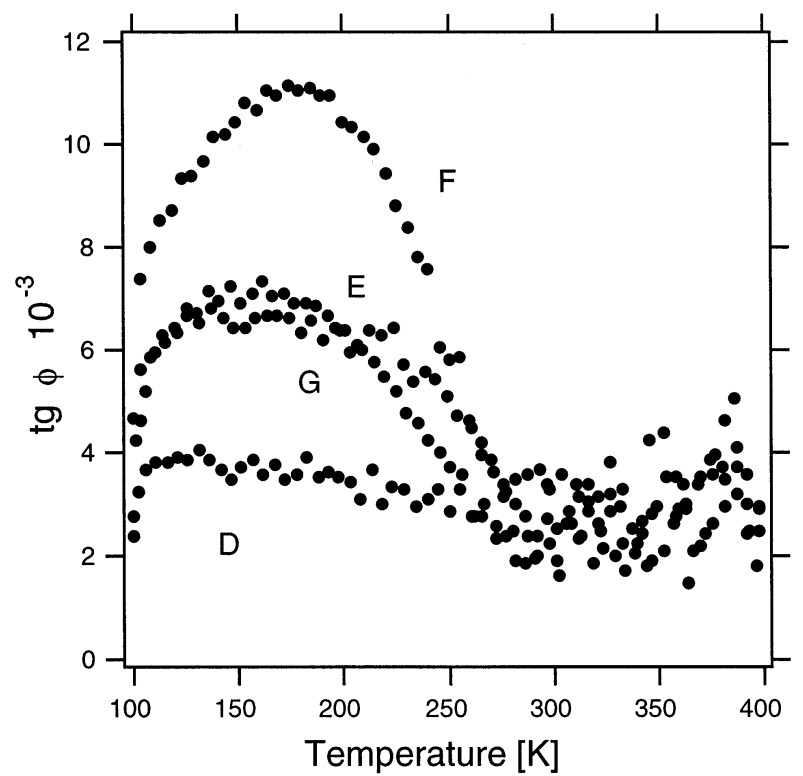

Fig. 10. Mechanical loss spectra for $\mathrm{Al}-4 \mathrm{wt} . \% \mathrm{Cu}-1 \mathrm{wt} . \% \mathrm{Mg}-$ $0.5 \mathrm{wt} . \% \mathrm{Ag}$ reinforced with $25 \mathrm{vol} . \%$ SAFFIL, processed with different fabrication parameters; $f=0.1 \mathrm{~Hz}, \varepsilon=10^{-5}, \mathrm{~d} T / \mathrm{d} t=2 \mathrm{~K} \mathrm{~min}^{-1}$, coolings. (Letters refer to Table 2).

infiltration process, the molten metal is never in contact with a metallic part that contains iron. Microhardness tests made in solution treated, water quenched and aged specimens show that the peak aged condition is obtained after artificial ageing of $4 \mathrm{~h}$ at $170^{\circ} \mathrm{C}$ (Fig. 8). This annealing time is certainly shorter than in the non-reinforced alloy as demonstrated by Parrini et al. [13] in the case of the $\mathrm{Al}-4 \mathrm{wt} . \% \mathrm{Cu}$ matrix.

The existence of micropores in the as-processed Albased MMCs is revealed by the measurements of the density (Fig. 9a) and of the elastic Young's modulus (Fig. 9b) which suggest that the microporosity is the lowest for the highest infiltration pressure (3 $\mathrm{MPa})$ as expected. The behaviour of the mechanical loss maximum at $200 \mathrm{~K}$ during thermal cycling is in good agreement with this presumption (Fig. 9c). Effectively, this maximum has been attributed to dislocation creation and motion near the interfaces originated in the thermal expansion mismatch between matrix and fibres [14-16]. Then, because cavities reduce the interfacial bonding strength, the lowest level of mechanical loss is expected for the highest degree of porosity. On the contrary, the best bonded interfaces should give rise to the highest mechanical loss maximum, as is the case of specimens infiltrated with a pressure of $3 \mathrm{MPa}$.

The evaluation of MMCs produced with different infiltration pressure, preform preheat and melt superheat, shows that the best performance (highest level for density, Young's modulus and mechanical loss maximum during cooling) is obtained after infiltration at 3 $\mathrm{MPa}$ with melt and preform temperatures equal to

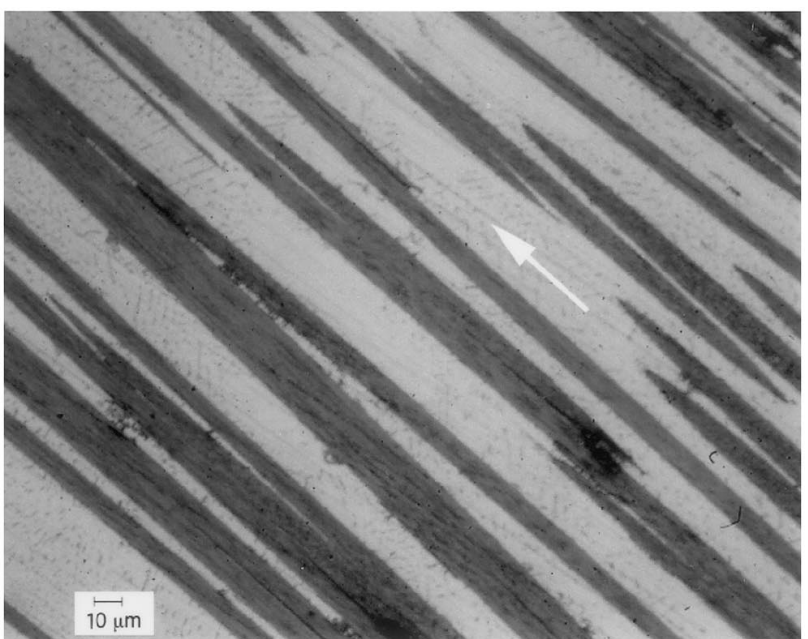

(a)

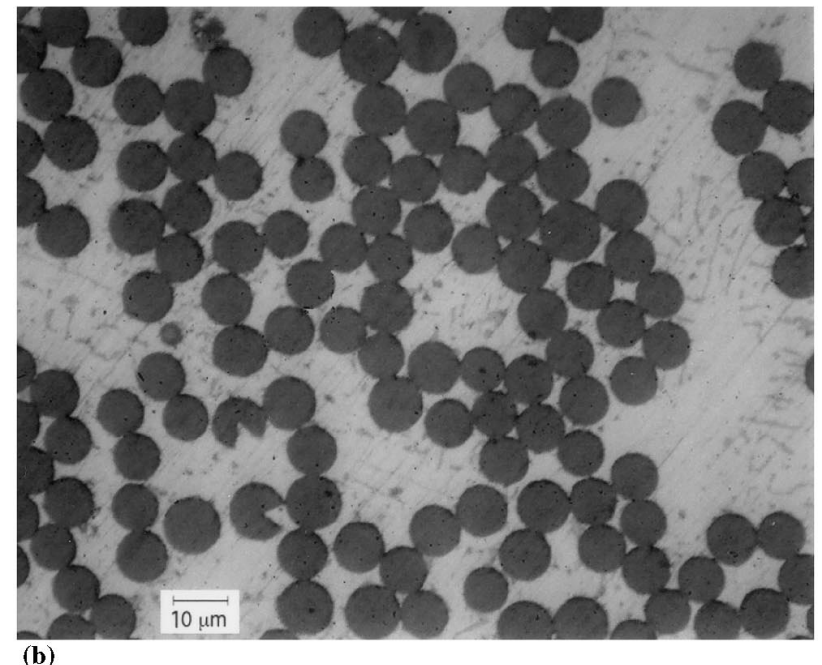

Fig. 11. Optical micrographs of polished sections from $\mathrm{Mg}-2 \mathrm{wt} . \% \mathrm{Si}-$ Carbon composites (a) parallel and (b) normal to the fibre direction. The white arrow indicates the infiltration direction. Precipitates of the $\mathrm{Mg}_{2} \mathrm{Si}$ phase are observable between the $\mathrm{C}$ fibres.

$750^{\circ} \mathrm{C}$ (see Table 2 and Fig. 10). Other tests have revealed that for lower melt temperatures the MMC porosity was higher. This would mean that the alloy viscosity was too high to achieve full infiltration of the ceramic preform. For higher melt temperatures, the mechanical properties were lower. This can be interpreted as due to the interface degradation by too long a contact time between the molten metal and the ceramic preform.

Finally, preliminary tests have been carried out to produce long fibre reinforced and hybrid MMC. Fig. 11 shows a $\mathrm{Mg}-2 \mathrm{wt} . \% \mathrm{Si}$ matrix composite reinforced with continuous carbon fibres. The observation of both directions parallel and normal to fibres, shows that a good infiltration quality is obtained. In the metallic matrix one observes precipitation of the intermetallic $\mathrm{Mg}_{2} \mathrm{Si}$ phase. In addition, full infiltration of $\mathrm{Al}-$ 


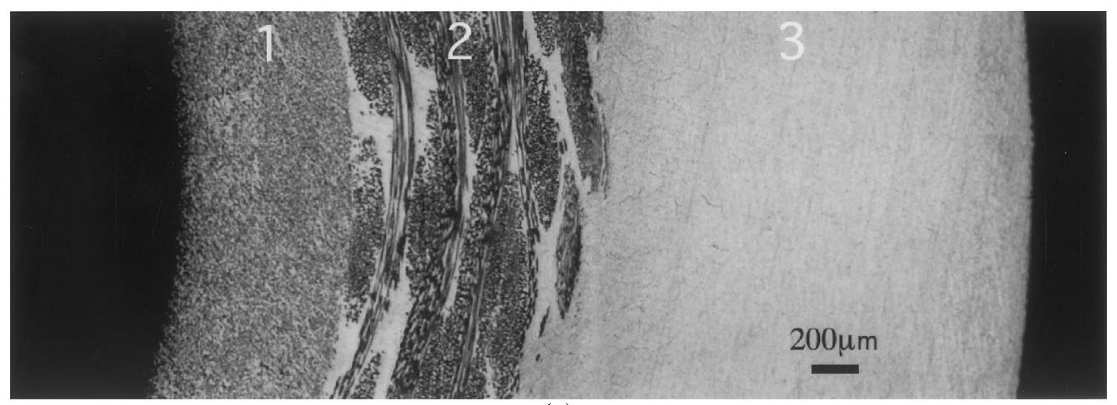

(a)

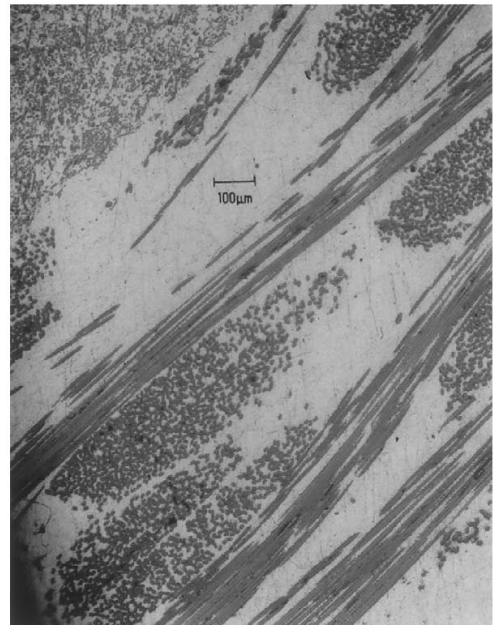

(b)

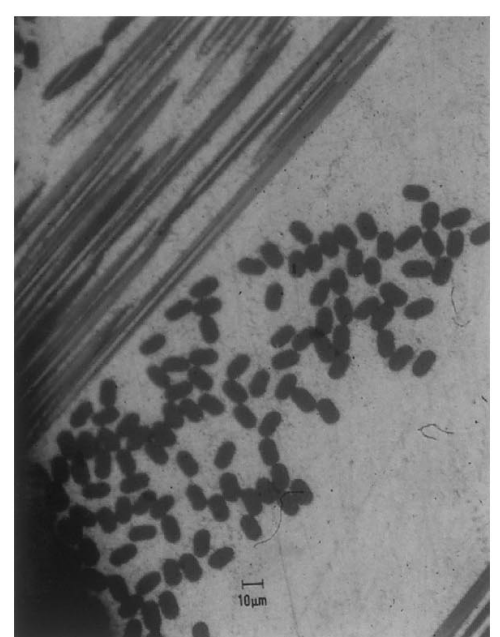

(c)

Fig. 12. (a) Optical micrographs of a hybrid MMC consisting in a core of $\mathrm{Al}-4 \mathrm{wt} . \% \mathrm{Cu}-1 \mathrm{wt} . \% \mathrm{Mg}-0.5 \mathrm{wt} . \% \mathrm{Ag}-\mathrm{SAFFIL}$ (1), an interlayer of $\mathrm{Al}-4 \mathrm{wt} . \% \mathrm{Cu}-1 \mathrm{wt} . \% \mathrm{Mg}-0.5 \mathrm{wt} . \% \mathrm{Ag}-\mathrm{Nextel}(2)$ and a surface layer of non-reinforced $\mathrm{Al}-4 \mathrm{wt} . \% \mathrm{Cu}-1 \mathrm{wt} . \% \mathrm{Mg}-0.5 \mathrm{wt} . \% \mathrm{Ag}(3)$. The observation in detail of the interlayer (b, c) shows that full infiltration of the continuous Nextel 440 fibres has been achieved.

4wt. $\% \mathrm{Cu}-1 \mathrm{wt} . \% \mathrm{Mg}-0.5 \mathrm{wt} . \% \mathrm{Ag}$ in complex preforms made of both short SAFFIL and long Nextel 440 alumina fibres was achieved with pressures of $3 \mathrm{MPa}$. The preforms consisted in a core of SAFFIL around which the Nextel fibres were wound. After infiltration, one obtains a core of $\mathrm{Al}-4 \mathrm{wt} . \% \mathrm{Cu}-1 \mathrm{wt} . \% \mathrm{Mg}-$ $0.5 \mathrm{wt} . \% \mathrm{Ag}$-SAFFIL surrounded by a long fibre (Nextel) reinforced interlayer and an non-reinforced metal surface layer. Fig. 12a shows the transverse section of a machined tube made of this hybrid composite. Details of the intermediate region are shown in the Fig. 12(b) and (c). The interest of this kind of material is to combine the high stiffness of long fibres with fatigue resistant surfaces. These developments are in progress.

\section{Conclusions}

A new apparatus has been developed which allows one to process MMCs by the gas pressure infiltration technique. This apparatus is composed of two parts: one melting chamber where the metallic alloy is melted under vacuum or protective atmosphere, and an injection chamber for preform preheating and gas pressure infiltration. In this configuration infiltration needs a low volume of high pressure gas, and consequently, the infiltration time is reduced and the operational safety is increased.

$\mathrm{Al}-4 \mathrm{wt} . \% \mathrm{Cu}-1 \mathrm{wt} . \% \mathrm{Mg}-0.5 \mathrm{wt} . \% \mathrm{Ag}-\mathrm{SAFFIL}$ composites have been produced with variable process parameters and then characterised by microscopical and mechanical tests.

Optical and scanning electron microscopy show that full infiltration was obtained with infiltration pressures between 1 and $3 \mathrm{MPa}$. An optimal thermal treatment has been found for these materials. It consists of a two-stage solution treatment of $2 \mathrm{~h}$ at $480^{\circ} \mathrm{C}+2 \mathrm{~h}$ at $500^{\circ} \mathrm{C}$ (necessary to dissolve the $\mathrm{Al}_{2} \mathrm{Cu}$ phase segregated around the fibres in the as-cast structure) followed by artificial ageing of $4 \mathrm{~h}$ at $170^{\circ} \mathrm{C}$ to reach the peak aged condition.

Measurement of Young's modulus, density, microhardness and mechanical loss show that the optimal process conditions for $\mathrm{Al}-4 \mathrm{wt} . \% \mathrm{Cu}-1 \mathrm{wt} . \% \mathrm{Mg}-$ $0.5 \mathrm{wt} . \% \mathrm{Ag}-\mathrm{SAFFIL}$ composites are a temperature of $750^{\circ} \mathrm{C}$ for both preform and melt and the maximum infiltration pressure of $3 \mathrm{MPa}$.

Infiltration of complex preforms consisting on an arrangement of both, short SAFFIL and long Nextel 440 fibres has been successfully achieved. In addition, 
continuous reinforced $\mathrm{Mg}-2 \mathrm{wt} . \% \mathrm{Si}-\mathrm{C}$ composites have been produced in preliminary tests. This features that the infiltration apparatus is suitable for the production of both continuous reinforced and hybrid MMC.

\section{Acknowledgements}

Authors specially acknowledge the technical support provided by B. Guisolan. Authors also acknowledge the support of the Centre Interdépartemental de Microscopie Electronique (CIME-EPFL) for the SEM observations. This research has been partially financed by the Swiss Priority Program on Materials Research, Project 2.1.B.

\section{References}

[1] M. Taya, R.J. Arsenault, Metal Matrix Composites, Pergamon Press, Oxford, 1989, pp. 51-63.

[2] M.M. Schwartz, Composite Materials Handbook, Mc GrawHill, New York, 1984.
[3] T.W. Clyne, J.F. Mason, Metall. Trans. A 18 (1987) 95.

[4] H. Fukunaga, K. Goda, Bull. Jpn. Soc. Mech. Engrs. 27 (1984) 1245.

[5] S. Long, Z. Zhang, H.M. Flower, Acta Metall. Mater. 43 (1995) 3489.

[6] S. Long, Z. Zhang, H.M. Flower, Acta Metall. Mater. 43 (1995) 3499.

[7] A. Mortensen, J.A. Cornie, M.C. Flemings, J. Met. 40 (1988) 12 .

[8] A. Mortensen, L.J. Masur, J.A. Cornie, M.C. Flemings, Metall. Trans. A 20 (1989) 2535.

[9] L.J. Masur, A. Mortensen, J.A. Cornie, M.C. Flemings, Metall. Trans. A 20 (1989) 2549.

[10] S. Nourbakhsh, H. Margolin, F.L. Liang, Metall. Trans. A 10 (1989) 2159.

[11] S. Nourbakhsh, F.L. Liang, H. Margolin, J. Phys. E 21 (1988) 898.

[12] A.S. Nowick, B.S. Berry, Anelastic Relaxation in Crystalline Solids, Academic Press, New York, 1972.

[13] L. Parrini, R. Schaller, Acta Metall. Mater. 43 (1995) 2149.

[14] A. Vincent, G. Lormand, S. Durieux, C. Girard, E. Maire, and R. Fougères, J. Phys. IV, 6, coll.C8 (1996) C8-719.

[15] L. Parrini, R. Schaller, Acta Mater. 44 (1996) 4881.

[16] E. Carreño-Morelli, S.E. Urreta, R. Schaller and L. Gabella, J. Physique IV, 6, coll.C8 (1996) C8-735. 